\title{
KERAJINAN TENUN PADA MASYARAKAT MUNA (Kasus Peranan Modal Manusia dan Modal Sosial Dalam Reproduksi Budaya Tenun di Kabupaten Muna)
}

\author{
Jamiludin* Andi Agustang** Sulaiman Samad***
}

\begin{abstract}
ABSTRAK
Mmasalah dalam penelitian ini adalah: (1) bagaimana fungsi modal manusia sebagai aktor utama dalam reproduksi, pengembangan dan pelestarian kerajinan tenun pada masyarakat Muna? (2) bagaimana fungsi modal sosial dalam membangun dan memgembangan relasi bisnis kerajinan tenun pada masyarakat Muna?

Pendekatan yang digunakan dalam penelitian ini adalah pendekatan kulaitatif yang merupakan suatu strategi penelitian yang menghasilkan keterangan atau data yang dapat mendeskripsikan realitas sosial dan kejadian-kejadian yang terkait dengan kehidupan masyarakat pengrajin tenun, sejarah, hubungan kekerabatan, dan kegiatan sosial, maka sasaran utama penelitian ini adalah menjelaskan atau mendeskripsikan reproduksi kultural kerajinan tenun pada masyarakat Muna. Data diperoleh dari 15 informan yang diambil secara purposive. Data yang diperoleh melalui observasi dan wawancara mendalam kemudian dianalisis secara induktif.

Hasil penelitian ini menunjukkan bahwa: (1) modal manusia (pengetahuan, pengalaman, kemampuan, keterampilan, kreativitas, dan inovasi) sebagai aktor utama sangat berpengaruh terhadap reproduksi kerajinan tenun, hal ini terlihat dari kualitas produksi yang dihasilkan, pengetahuan dan pengalaman dipadu dengan keterampilan mengasilkan kreativitas dan inovasi pelaku usaha berimplikasi pada meningkatnya kulitas dan kuantitas produksi; (2) fungsi modal sosial dari aspek kepercayaan telah terjaga dengan baik karena para pengrajin dan pengusaha tenun sangat mengutamakan kepercayaan dalam hubungan bisnis. Dari aspek nilai dan norma tetap dipertahankan dengan selalu berpegang teguh pada nilai dan norma yang berlaku dalam masyarakat. Aspek jaringan, para pengrajin sudah membentuk jaringan pemasaran, baik di tingkat kabupaten, provinsi, nasional.

Kata Kunci: Kerajinan Tenun, Reproduksi cultural, Modal manusia. Modal Sosial
\end{abstract}

\section{PENDAHULUAN}

Kerajinan tenun merupakan salah satu bentuk kearifan lokal. Kearifan lokal didefinisikan sebagai suatu kekayaan budaya lokal yang mengandung kebijakan hidup; pandangan hidup (way of life) yang mengakomodasi kebijakan (wisdom) dan kearifan hidup. Di Indonesia, kearifan lokal tidak hanya berlaku secara lokal pada budaya atau etnik tertentu, tetapi dapat dikatakan bersifat lintas budaya atau lintas etnik sehingga membentuk nilai budaya yang bersifat nasional. Sebagai contoh, hampir di setiap budaya lokal di Nusantara dikenal kearifan lokal yang mengajarkan gotong royong, toleransi, etos kerja, dan seterusnya (Agustang, 2010). Walaupun tidak ada jaminan bahwa kearifan lokal akan tetap kukuh menghadapi globalisasi yang menawarkan gaya hidup yang makin pragmatis dan konsumtif. Secara faktual 
dapat kita saksikan bagaimana kearifan lokal yang sarat kebijakan dan filosofi hidup nyaris tidak terimplementasikan dalam praktik hidup yang makin pragmatis.

Pengetahuan bertenun telah lama dikenal di daerah Muna yang yang diperkirakan telah ada sejak abad ke-14, pada masa pemerintahan Sugi Manuru, raja Muna ke-6. Kegiatan menenun ini merupakan salah satu bentuk kearifan lokal yang masih hidup dan berkembang serta masih dipertahankan oleh masyarakatnya. Pengetahuan bertenun ini dimiliki secara merata diseluruh daerah Muna. Namun sekarang ini, pengetahuan bertenun ini mulai memudar dan dan secara bertahap mulai ditinggal pendukungnya. Kepandaian menenun yang diperoleh secara turun temurun sejak zaman dahulu, sampai sekarang harus dapat diwariskan dari generasi ke generasi

Kerajinan tenun Muna merupakan salah satu local genius yang potensial dikembangkan menjadi klaster industri dibawah koordinasi Dinas Koperasi dan Usaha Kecil dan Menengah, Dinas Parawisata dan Ekonomi Kreatif, Dinas Perindustrian dan Perdagangan Propinsi Sulawesi Tenggara dan Kabupaten Muna. Gencarnya promosi ke berbagai tempat (lokal, nasional, dan internasional dan festifal kerajinan tenun mulai dilaksanakan sejak tahun 2008 sampai dengan saat ini, serta adanya kebijakan pemerintah propinsi maupun kabupaten, antara lain; penggunaan pakain berbahan dasar tenun sekali dalam seminggu pada semua instansi pemerintah maupun swasta, penggunaan pakaian tenun dalam acara-acara resmi pemerintah, selain digunakan pada upacara-upacara adat. Kebijakan pemerintah ini merupakan angin segar bagi tumbuh kembangnya peluang usaha kerajinan tenun di Kabupaten Muna.

Masalah yang sedang dihadapi kerajinan tenun Muna sebagi industri kreatif adalah rendahnya kualitas sumberdaya manusianya, sebagaimana diungkapkan oleh Kepala Dinas Koperasi dan UKM Kabupaten Muna, Madi Yusuf, bahwa kendala utama yang dihadapi kerajinan tenun adalah kualitas sumber daya manusianya, karena rata-rata pendidikan pengrajin hanyalah tamatan sekolah dasar atau tidak tamat SD, hanya sebahagian kecil saja yang tamat SMP dan SMA. Implikasi dari kondisi pendidikan dari pengrajin ini adalah rendahnya kreativitas dan inovasi yang dilakukan oleh pengrajin, padahal tuntutan konsumen menghendaki penganekaragaman produk sehingga mampu bersaing dengan produk-produk lain yang sejenis. Oleh karena itu, sentuhan seni dari tangan pengrajin, disainer motif yang kreatif dan inovatif sangat dibutuhkan dalam mewujudkan karya cipta yang elegan, menarik, dan tidak monoton.

Terkait dengan modal sosial, masyarakat yang memiliki modal sosial tinggi antara lain rendahnya angka tindakan kriminal dan sedikitnya jumlah kebijakan formal, namun jika modal sosial rendah maka kerja sama antar orang hanya dapat berlangsung dalam sistem hukum dan regulasi yang bersifat formal. Modal sosial tinggi hanya akan tercipta bila ada sikap resprositas yang tinggi. Artinya interaksi bukan semata-mata hanya sebagai pertukaran yang penuh perhitungan, tetapi kombinasi antara sifat altruis jangka pendek dan harapan keuntungan jangka panjang (Agustang, 1999). Modal sosial barulah bernilai ekonomi kalau dapat membantu 
individu dalam kelompok, misalnya untuk mengakses sumber-sumber keuangan, mendapatkan informasi, menemukan pekerjaan, merintis usaha, dan meminimalkan biaya transaksi (Tonkins, 2000).

Komponen-komponen modal sosial seharusnya dapat dimanfaatkan oleh pelaku usaha kerajinan tenun Muna secara maksimal, misalnya saja kepercayaan dimanfaatkan oleh individu pelaku usaha untuk membangun komitmen dengan pihak lain dalam mempertahankan kerja sama yang sudah terjalin, jaringan dimanfaatkan oleh individu pelaku usaha untuk mendapatkan pasar, kerja sama, bantuan alat, dan modal lainnya.

Berdasarkan latar belakang tersebut di atas, maka masalah dapat dirumuskan; 1). Bagaimana fungsi modal manusia sebagai aktor utama dalam reproduksi budaya kerajinan tenun pada masyarakat Muna? 2). Bagaimana fungsi modal sosial dalam memgembangan relasi bisnis sebagai reproduksi budaya kerajinan tenun pada masyarakat Muna?

\section{METODE PENELITIAN}

Jenis penelitian yang digunakan adalah penelitian kualitatif, mengikuti pendapat (Andi Agustang, 2015) bahwa realitas sosial dipandang sebagai sesuatu yang holistic (utuh), kompleks, dinamis, penuh makna, dan hubungan yang bersifat interaktif.

Menurut sumbernya, data yang digali dapat dibedakan menjadi dua macam, yakni data primer dan data sekunder. Data primer merupakan data yang diperoleh langsung dari lapangan, baik melalui wawancara mendalam dari pengrajin tenun gedokan maupun ATBM, tokoh adat, kepala desa, camat, kepala dinas, LSM, serta warga masyarakat yang direkrut secara acak, pengamatan terlibat, maupun diskusi terfokus. Data sekunder adalah data yang diperoleh melalui studi kepustakaan yang berupa buku-buku, hasil penelitian orang lain atau sumber informasi ilmiah lainnya yang relevan dengan masalah dalam penelitian ini.

Agar kerja penelitian berlangsung sesuai rencana, maka penelitian ini menggunakan beberapa sarana teknis penelitian sebagai instrumen, yaitu kartu-kartu data, pedoman wancara, pedoman observasi. Kartu-kartu data digunakan untuk pencatatan, kategorisasi data, dan klasifikasi data. Pedoman wawancara digunakan sebagai pengarah dalam berlangsungnya wawancara, demikian pula dengan pedoman observasi digunakan untuk memudahkan peneliti dalam melakukan pengamatan terhadap obyek yang diteliti. Selain itu digunakan pula kamera foto, kamera video untuk merekam hasil pengamatan, serta tape recorder untuk merekam hasil wawancara

Analisis data digunakan tiga tahapan yaitu tahap reduksi data, penyejian data, dan tahap verifikasi data. Sedangkan tahap pengabsahan data dilakukan dengan cara trianggulasi, perpanjangan pengamatan, member cek, dan meningkatkan ketekunan, 


\section{HASIL PENELITIAN DAN PEMBAHASAN}

\section{Fungsi Modal Manusia Dalam Reproduksi Kerajinan Tenun Pada Masyarakat Muna}

Pada bagian ini, peneniti akan menjelaskan informasi yang diperoleh dari informan terhadap sepuluh informan mengenai perkembangan kerajinan tenun Muna dan fungsi modal manusia dalam reproduksi, pengembangan dan pelestarian kerajinan tenun Muna sebagai industri ekonomi kreatif. Analisis informasi yang diperoleh melalui wawancara perihal modal manusia. Edwison dan Malone (1977) "human capitals the individual knowledge, experience, capability, skill, creatifity, innovation" yang diterjemahkan secara bebas bahwa modal manusia adalah sesuatu yang dimilki individu yang terdiri dari aspek pengetahuan, pengalaman, kemampuan, keterampilan, kreativitas, dan inovasi

\section{a. Aspek Pengetahuan}

Pengetahuan merupakan salah satu faktor yang mempengaruhi aktivitas manusia. Pengetahuan yang dimaksud dalam penelitian ini adalah pengetahuan yang diperoleh oleh seorang individu, baik yang diperoleh melalui pendidikan formal, non formal maupun pendidikan informal yang membantu seseorang atau sekelompok orang dalam menyelesaikan pekerjaan sehari-hari.

Temuan dalam penelitian ini menunjukkan bahwa pengetahuan sangat berpengaruh dalam reproduksi, pengembangan dan pelestarian kerajinan tenun sebagaimana telah diuraikan oleh para informan. Informan WN menjelaskan bahwa pengetahuan yang dimilikinya dalam bertenun tidaklah diperoleh dari pendidikan formal, akan tetapi ia peroleh dari pendidikan informal. Menurut WN ketika berusia 10 tahun ia mulai membantu ibunya, mula-mula diberi tugas menggulung benang, kemuadian bersama-sama dengan orang tuanya melakukan kegiatan menghani. Pada waktu itu orang tuanya belum memberi kepercayaan kepadanya untuk menenun, tetapi secara diam-diam ia melakukan pekerjaan menenun ketika ibunya tidak ada di tempat. Dari kerja menenun secara sembunyi-sembunyi tadi akhirnya pengetahuan bertenun secara perlahan tapi pasti mulai dikuasainya yang pada akhirnya menjadi penenun yang mandiri

Sama seperti informan di atas, informan WI mengatakan bahwa pengetahuan bertenun yang dimilikinya diperoleh dari orang tuanya. Orang tuanya memperoleh pengetahuan menenun dari neneknya, dan seterusnya. Singkatnya, WI adalah keluarga penenun, keturunan penenun, pengetahuannya dalam menenun diwarisi secara turun temurun. Dalam suatu kesempatan WI berceritera bahwa pengetahuannya menenun bermula ketika duduk di bangku Sekolah Dasar, WI selalu diminta ibunya untuk membantu menghani sepulang dari sekolah. Kebiasaan menghani ini selalu dilakukan sampai dengan tamat SD. Setelah masuk SMP, WI mulai memberanikan diri menenun sewaktu-waktu menggantikan ibunya. Setelah tamat SMP, WI mulai bertenun secara mandiri meskipun kain tenun yang dibuatnya masih sangat sederhana. Akan tetapi seiring berjalannya waktu pengetahuan bertenun ini mulai dikuasainya yang kemudian mengantarkannya sebagai pekerjaan tetapnya. 
Lain halnya dengan WR yang tidak terlahir dari keluarga penenun sebagaimana informan lainnya. Dari pengakuannya tidak seorang pun dari anggota keluarganya yang berprofesi sebagai penenun. Ketertarikannya sebagai penenun bermula ketika menjelang remaja (sekitar umur 15 tahun) berkunjung ke rumah tetangga yang sedang menenun, dan seketika itu pula WR tertarik untuk belajar menenun. Sejak saat itu WR secara rutin belajar menenun dari tetangganya yang pada akhirnya informan ini ikut bekerja sebagai penenun. Mula-mula ia menenun sebagai pekerja upahan, kemudian setelah merasa cukup barulah ia menjadi pekerja mandiri.

Pengetahuan merupakan hasil dari tahu, dan ini terjadi setelah seseorang melakukan penginderaan terhadap suatu obyek tertentu. Penginderaan terjadi melalui panca indra manusia, yaitu indra penglihatan, pendengaran, penciuman, perasaan dan perabaan. Sebahagian besar pengetahuan yang dimiliki manusia diperoleh melalui mata dan telinga (Notoatmojo, 2007).

Menurut pendekatan kontruktivistis, pengetahuan bukanlah fakta dari suatu kenyataan yang sedang dipelajari, melainkan sebagai konstruksi kognitif seseorang terhadap obyek, pengalaman, maupun lingkungannya. Pengetahuan bukanlah sesuatu yang sudah ada dan tersedia dan sementara orang lain tinggal menerimanya. Pengetahuan adalah sebagai suatu pembentukan yang terus menerus oleh seseorang yang setiap saat mengalami reorganisasi karena adanya pemahaman-pemahaman baru.

\section{b. Aspek Pengalaman}

Teori modal manusia berfokus pada individu sebagai unit analisisnya, yang menekankan bahwa investasi pengusaha sebagai atribut kunci (misalnya pendidikan, pelatihan, dan pengalaman) yang terkait dengan kompetensi dan keterampilan yang mungkin untuk meningkatkan kinerja bisnis (Becker, 1993). Pengusaha dengan kompetensi dan keterampilan yang lebih beragam cenderung efektif untuk mengatur dan mengelola proses produksi dan cenderung memiliki usaha yang lebih sukses.

Sehubungan dengan hal tersebut di atas, hasil penelitian ini menunjukkan bahwa informan WN telah menekuni kerajinan tenun Muna sejak usia 10 tahun dan sekarang ini usianya telah mencapai 59 tahun, dengan demikian maka informan telah menggeluti pekerjaan menenun selama 49 tahun. Sebuah pengalaman panjang yang tidak mudah dilalui oleh seorang penenun. Menurutnya, banyak hal yang telah dilaluinya terutama bekerkaitan dengan pekerjaannya sebagai penenun, terutama dalam mengasilkan produk-produk kerajinan tenun. Menurut informan WN, kerajinan tenun Muna membutuhkan kesabaran, ketekunan, ketelitian dan konsentrasi yang tinggi, karena jika tidak demikian maka benang yang sudah dirajut bisa putus, motif yang sudah didesain bisa rusak, dan kualitas produksinya juga tidak maksimal serta waktu pengerjaannya juga semakin lama. Pengalaman tentu saja salah satu faktor yang tidak dapat diabaikan dalam meningkatkan jumlah dan kualitas produksi. Semakin lama menekuni pekerjaan menenun maka semakin banyak pula jumlah dan kualitas barang yang dihasilkan yang tentu saja berbeda dengan yang belum berpengalaman. 
Pengalaman adalah guru yang terbaik, itulah pepatah klasik yang sering diucapkan orang. Pepatah ini berlaku pula bagi informan WI. Pengalamannya dalam menekuni kerajinan tenun Muna selama kurang lebih 50 tahun adalah bukan waktu yang singkat. Telah banyak dilaluinya pahit manisnya usaha kerajinan tenun yang ditekuninya, akan tetapi pengalamannya telah menempanya menjadi penenun yang handal sebagaimana dikemukakan bahwa "saya telah menenun sejak kecil sampai dengan sekarang, tidak terhitung lagi berapa jumlah kain tenun yang saya hasilkan, saya dapat membuat berbagai motif kain, saya dapat mendisain motif sesuai dengan selera konsumen, kesemuanya itu saya peroleh karena pengalaman yang panjang

Senada dengan hal di atas, pengalaman WM sebagai penenun kurang lebih sudah 37 tahun. Ia telah menjalani profesi sebagai penenun sejak usia 15 tahun. Pengalaman yang panjang telah menempanya menjadi penenun yang handal. Untuk mengembangkan keterampilan menenun yang sudah diperoleh sebelumnya, maka setiap ada pelatihan pengembangan keterampilan terutama berkaitan dengan disain motif yang diselenggarakan oleh Dinas Perindustrian dan Perdagangan Kabupaten Muna maupun pihak lain (LSM) selalu diikuti. Pada tahun 2004, informan mengikuti pelatihan pembuatan disain motif dan pada tahun 2012 mengikuti pelatihan penggunaan ATBM sebagai alat produksi tenun.

Pengalaman seseorang dalam menekuni suatu pekerjaan kadang-kadang menjadi acuan dalam melihat sampai sebarapa jauh seseorang menguasai dan ahli dalam bidang pekerjaan tertentu. Industri kerajinan tenun membutuhkan pengalaman khusus untuk menjadi trampil dan ahli dalam mendisain motif dan melakukan kreasikreasi baru.

Kajian tentang pencapaian kualitas sumber daya manusia mulai mendapat perhatian pemerintah dari berbagai negara seperti yang terjadi di Amerika Serikat. Penelitian Bates (2005) telah membuktikan bahwa meskipun industri kecil mendapat pemberian modal yang besar saat memulai bisnis (start-up), namun tetap gagal karena diyakini akibat pencapaian yang lebih rendah dalam pendidikan dan pengalaman yang spesifik bidang bisnis yang digeluti. Inilah mengapa pengalaman dianggap sebagai salah satu faktor modal manusia yang berpengaruh terhadap perkembangan industri kerajinan tenun Muna. Keterlibatan seseorang dalam suatu pekerjaan atau profesi dalam periode atau waktu tertentu akan meningkatkan keterampilan dan keahliannya dalam bidang tersebut.

\section{c. Aspek Kemampuan}

Hasil penelitian ini menunjukan bahwa kemampuan seorang penenun diperoleh melalui pendidikan dalam keluarga, dalam lingkungan sekolah maupun lewat pendidikan luar sekolah, sebagaimana dikemukakan oleh informan WN bahwa kemampuan dasar menenun $\mathrm{WN}$ diperoleh dari orang tua, akan tetapi dalam hal pemberian motif pada kain sarung yang ditenun dipelajari sendiri secara otodidak, tidak ada satu motifpun yang tidak dapat dikerjakan, yang penting diberi contoh, atau melihat motif yang diinginkan, informan WN langsung dapat mengerjakannya, mungkin karena WN keturunan penenun sehingga cepat memahami motif tenun yang diinginkan konsumen. 
Selain yang disebutkan di atas, satu hal yang tidak kalah penting dalam kerajinan tenun adalah aspek keterampilan karena bagaimanapun pengetahuan yang dimiliki seseorang tidak akan bermanfaat apabila tidak terampil dalam memanfaatkannya. Oleh karena itu, menurut informan WN, keterampilan dalam menenun kain tenun Muna dalam berbagai motif dan berbagai jenis benang mutlak dibutuhkan. Untuk diketahui ada 16 jenis motif kain tenun Muna yang berhasil dikembangkan saat ini, yang masing-masing jenis memiliki tingkat kesulitan sendirisendiri, dari yang paling sederhana dan mudah dikerjakan sampai dengan paling sulit dan rumit.

Sejalan dengan informan di atas, informan WT mengatakan bahwa keterampilan menenun diperoleh dari orang tua yang diwariskan secara turun temurun, tidak diperoleh dari pendidikan formal, karena memang pada masa itu belum ada sekolah khusus penenun. Menurut informan WT bahwa untuk mengasah dan mengembangkan keterampilan dalam menenun WT banyak melakukan latihan sehingga secara perlahan ia menguasai dan terampil dalam menenun. Selain itu, untuk mengembangkan kemampuan disain, pernah mengikuti pelatihan pengembangan disain motif yang diselenggarakan oleh Dinas Perdagangan dan Perindustrian Kabupaten Muna. Dari hasil pelatihan tersebut, WT dapat menguasai dan terampil membuat kain tenun dalam berbagai jenis dan motif, dari yang paling sederhana sampai dengan motif yang paling sulit dan kompleks.

Hasil wawancara di atas, menunjukkan bahwa dalam kerajinan tenun Muna dipengaruhi oleh kemampuan penenun dalam menjalankan profesinya sebagai pengrajin. Stokckey (2003) menjelaskan bahwa modal manusia adalah konsep yang menjelaskan manusia dalam organisasi dan bisnis merupakan asset penting dan beresensi yang memiliki sumbangan terhadap pengembangan dan pertumbuhan sama seperti halnya asset fisik seperti mesin dan modal kerja. Sikap dan skill serta kemampuan manusia memiliki kontribusi terhadap kinerja dan produktifitas organisasi. Pengeluaran untuk pelatihan, pengembangan, kesehatan dan dukungan merupakan investasi.

Uraian di atas menunjukkan bahwa modal manusia sebagaimana modal-modal lainnya sangat diperlukan dalam untuk meningkatkan taraf dan kualitas hidup dalam berbagai aspek kehidupan, baik dalam bidang ekonomi, sosial budaya, politik maupun keagamaan, modal manusia mengacu pada kumpulan pengetahuan dan keterampilan yang melekat pada kemampuan individu untuk melaksanakan pekerjaan yang kemudian menhgasilkan benda ekonomi (Wikipedia 2009).

Terkait dengan kemampuan atau kompetensi Spenser dan Spenser dalam Anwas (2013), dalam individu terdapat lima tipe kompetensi, yaitu; 1) motif (motives), kompetensi yang berkaitan dengan kemampuan individu yang konsisten dan mendorongnya melakukan tindakan, 2) sifat bawaan (traits), kompetensi yang berkaitan dengan karakter atau watak mandiri yang menjadikan individu berprilaku tertentu. Sifat bawaan ini antara lain; percaya diri, daya tahan, dan lain-lain, 3) konsep diri (self consept), kompetensi yang berkaitan dengan sikap dan nilai-nilai yang dimiliki individu, 4) pengetahuan (knowledge0, kompetensi yang berkaitan 
dengan informasi atau ilmu yang dimiliki individu dalam bidang pekerjaan tertentu, 5) keterampilan (skills), kompetensi yang dimiliki individu berkaitan dengan pekerjaan fisik atau mental individu.

\section{d. Aspek Kreativitas dan Inovasi}

Aspek kreativitas dan inovasi dalam penelitian ini dapat diartikan sebagai proses dan hasil pengembangan dan pemanfaatan pengetahuan, pengalaman, dan keterampilan yang menciptakan dan meningkatkan kualitas dan kuantitas produksi barang dan jasa sehingga memberikan nilai tambah yang sangat berarti bagi kesejahtraan masyarakat penenun.

Hasil temuan dalam penelitian ini menunjukkan bahwa kreativitas sangat berpengaruh terhadap pengembangan kerajinan tenun Muna, seperti dikemukakan oleh informan WN bahwa kreativitas menjadi unsur penting dalam membuat disain atau motif, semakin banyak motif yang diciptakan makan semakin banyak pula peminat terhadap hasil kerajinan tenun. Motif menjadi salah satu daya pikat kerajinan tenun Muna.

Sejalan dengan informan di atas, informan WT mengatakan bahwa kreativitas dalam mengerjakan kain tenun sangat penting dalam industeri kerajinan tenun. Informan WT sudah tidak diragukan lagi kemampuan dan kreativitasnya, tidak hentihentinya ia melakukan kreasi-kreasi baru terutama dalam pembuatan disain motif. Hal ini dimaksudkan agar bisa bersaing dengan produk-produk sejenis yang mulai merambah pasar-pasar tradisional. Jenis motif yang dikerjakan adalah "leja, kumbaea, bhia-bhia, samasili", kemudian dikembangkan menjadi beberapa motif sesuai pesanan dan keinginan pembeli.

Lain halnya dengan inovasi teknologi yang dilakukan WM yaitu dengan menerapkan ATBM sebagai alat untuk memproduksi kain tenun. Menurut informan, ada perbedaan yang cukup signifikan antara hasil produksi yang menggunakan ATBM dengan alat tenun gedokan baik dari segi kualitas maupun kuantitas. Dari segi kualitas hasil produksi tenun ATBM lebih halus dibandingkan dengan hasil produksi tenun gedokan. Dari segi kuantitas, jumlah produksi tenun ATBM lebih banyak dibanding hasil produksi alat tenun gedokan. Satu lembar kain dikerjakan dengan menggunakan ATBM antara 1-2 hari, sehingga dalam satu bulan dapat mengasilkan antara 20-25 lembar kain, sedangkan 1 lembar kain dikerjakan dengan menggunakan alat tenun gedokan antara 3-4 hari, sehingga dalam 1 bulan dapat memproduksi antara 8-9 lembar kain tenun. Begitu pula dengan yang dilakukan oleh informan $\mathrm{M}$, mengakui bahwa kalau seorang pengrajin ingin digemari produk-produknya oleh konsumen maka harus bisa melakukan uji coba membuat kreasi-kreasi baru terutama berkaitan dengan motif. Menurutnya keunggulan kain tenun Muna dan menjadi cirri khas tenun Muna adalah tenun "Sobi" (tenun yang bermotif) sedangkan kain tenun lain yang ditemukan di Indonesia tidak bermotif yang disebut dengan tenun datar.

Berdasarkan penjelasan dan hasil wawancara dengan para informan dalam penelitian ini menunjukkan bahwa peran modal manusia dalam pengembangan dan pelestarian industri kerajinan tenun Muna sangat penting sehingga tidak hentihentinya dari berbagai pihak dalam melakukan pembinaan dan pengembangan 
sumberdaya manusia. Bates (2005) dalam penelitiannya di Amerika Serikat telah membuktikan bahwa meskipun industri kecil mendapat pemberian modal besar (modalisasi) saat memulai bisnis (start up), namun tetap gagal karena diyakini akibat pencapaian yang lebih rendah dalam pendidikan dan pengalaman spesifik bidang bisnis yang digeluti. Demikian pula penelitian yang dilakukan pada industry kecil di Indonesia, berbagai bentuk bantuan modal dan insentif telah diberikan oleh pemerintah Indonesia, namun semuanya belum memberikan hasil yang menggembirakan (Thee, 2006). Walaupun harus diakui bahwa modal manusia diyakini memiliki peran penting dalam perekonomian dan bisnis namun berbagai penelitian tersebut gagal membuktikan signifikansinya.

Pengetahuan para pengrajin tenun Muna rata-rata diperoleh melalui pewarisan dari orang tua mereka atau dengan kata lain pengetahuan yang mereka miliki dalam bertenun diperoleh bermula dari melihat orang tua mereka yang lama kelamaan mereka menjadi pintar. Hal ini disebabkan di daerah (Muna) tidak ada sekolah khusus menenun. Pengetahuan yang diperoleh sebelumnya diperdalam melalui pendidikan non formal, yaitu melalui pelatihan-pelatihan yang diselenggarakan berbagai pihak, baik yang dilakukan oleh pemerintah, LSM, maupun pihak swasta. Menurut Suryadi dalam Damsar (2010) bahwa modal manusia menunjuk pada modal tenaga kerja yang merupakan pemegang kapital (capital holder) sebagaimana tercermin di dalam keterampilan, pengetahuan, dan produktivitas kerja seseorang.

Modal manusia adalah perpaduan antara pengetahuan, pengalaman, kemampuan dan keterampilan yang menghailkan kreativitas dan inovasi sehingga seseorang atau sekelompok orang dapat melakukan kreasi-kreasi dan inovasi baru sebagaimana dilakukan oleh pengrajin-pengrajin tenun di Kabupaten Muna yang pada gilirannya tidak saja menambah kualitas barang tetapi juga dapat meningkatkan kesejahteraan mereka karena barang/tenunan yang mereka produksi nilainya bertambah baik dari segi kuantitas maupun kualitas produksi.

\section{Fungsi Modal Sosial Dalam Pengembangan Jaringan Bisnis Reproduksi Budaya Kerajinan Tenun pada Masyarakat Muna}

Arsyad, dkk. (2011) yang menyatakan bahwa modal sosial juga merupakan sebuah fenomena yang tumbuh dari bawah (bottom-up phenomenon), yang berasal dari sekumpulan individu yang membentuk pola jalinan sosial (sosial network) yang didasarkan atas prinsip saling mempercayai (trust), resiprositas sosial, norma dalam berperilaku, serta aksi kolektif.

Elemen-elemen modal sosial yang dikemukakan di atas, menjadi sumber munculnya interaksi antara orang-orang dalam suatu komunitas. Hasil dari interaksi tersebut menjadi parameter pengukuran modal sosial, seperti tercipta dan terpeliharanya kepercayaan antarwarga masyarakat. Selain itu, interaksi tersebut dapat terjadi dalam skala individual maupun institusional. Secara individual, interaksi terjadi melalui hubungan antar individu kemudian akan melahirkan ikatan emosional antara dua individu maupun dalam kelompok. Secara institusional, interaksi dapat lahir pada saat tujuan suatu organisasi memiliki kesamaan dengan organisasi lainnya. 
Untuk mengukur interaksi tersebut, ada tiga para meter modal yang dapat digunakan untuk menganalisis hasil penelitian pada fungsi modal sosial dalam pengembangan relasi bisnis dan pelestarian kerajinan tenun di Kabupaten Muna yaitu; kepercayaan (trust), norma (norms), dan jaringan (networks).

\section{Aspek Kepercayaan}

Sebagaimana dijelaskan Fukuyama (1995), kepercayaan adalah harapan yang tumbuh di dalam sebuah masyarakat yang ditunjukkan oleh adanya perilaku jujur, teratur, dan kerjasama berdasarkan norma-norma yang dianut bersama.

Hasil wawancara mendalam yang dilakukan dengan Informan WN mengatakan bahwa ada bebera aspek yang harus diperhatikan untuk menjaga kepercayaan konsumen, yaitu pertama kualitas kain tenun harus terjaga, kedua ketepatan waktu pengerjaan, jika konsumen menginginkan waktu penyelesaian adalah 3 hari maka harus ditepati, ketiga, harganya bersaing, artinya tidak boleh terlalu jauh perbedaan harga dengan penenun lain.

Aspek kepercayaan menjadi hal utama dalam kegiatan bisnis, termasuk usaha kerajinan tenun. Karena itu menurut informan (wawancara, Agustus 2015) bahwa selama 50 tahun menjadi penenun, kepercayaan konsumen menjadi prioritas utama, prinsipnya adalah kepuasan konsumen. Kepercayaan dan kepuasan konsumen menjadi perekat antara dirinya dengan pelanggan. Dalam memproduksi kain tenun pesanan pelanggan sedapat mungkin dipenuhi baik dari segi kualitas, ketepatan waktu pekerjaan dan harga yang ditawarkan. Menurut informan, selama ini belum pernah ada pelanggan, baik yang datang dari kota Raha maupun dari luar Kabupaten Muna yang complain terhadap kain tenun yang diproduksinya

Kepercayaan adalah salah salah satu modal penting dalam memulai sebuah usaha kerajinan tenun. Hal ini disebabkan karena sebuah produk budaya haruslah memperhatikan aspek kepercayaan dari konsumen. Informan WD mengatakan bahwa bila ada konsumen yang memesan barang hasil tenunan, sedapat mungkin barang yang dikerjakannya harus memiliki standar kualitas yang baik, ketepatan pengerjaan sesuai kesepakatan kerja

Menurut informan WT, karena kepercayaan konsumen pulalah menjadikan dia tetap bertahan sebagai penenun selama kurang lebih 60 tahun. Oleh karena itu, baginya kepercayaan yang telah diberikan pelanggan harus menjadi perhatian utama. Selain itu, informan juga selalu menjalin saling percaya dengan pedagang-pedagang keliling yang selama ini telah berjasa ikut memasarkan barang-barang tenunannya. Kepercayaan harus menjadi modal utama, karena kain tenun yang mereka ambil biasanya tidak dibayar tunai, akan tetapi nanti terjual barulah dibayarkan

Menurut informan $\mathrm{S}$ hubungan antara pekerja dengan pengusaha tenun adalah hubungan yang tercipta karena saling percaya, saling menguntungkan sehingga hubungan mereka bukanlah hubungan antara pekerja dan majikan tetapi hubungan antar kolega, dimana hubungan itu tercipta karena adanya saling ketergantungan antara pekerja dan pemilaik usaha. Yang menarik disini adalah bahwa alat yang digunakan dalam menenun bukanlah pemilik usaha, akan tetapi milik pribadi 
penenun. Dan tempat pengerjaannya pun bukan di rumah sang pengusaha tetapi di rumah penenun.

Hasbullah (2006) menjelaskan bahwa rasa percaya adalah suatu bentuk keinginan untuk mengambil resiko dalam hubungan-hubungan sosial yang didasari perasaan yakin bahwa orang lain akan melakukan sesuatu seperti yang diharapkan dan akan selalu bertindak dalam suatu pola yang saling mendukung. Rasa percaya menjadi pilar kekuatan dalam modal sosial. Seseorang akan melakukan apa saja untuk orang lain kalau ia yakin bahwa orang tersebut akan membawanya ke arah yang ia inginkan. Rasa percaya dapat membuat orang bertindak sebagaimana yang diarahkan oleh orang lain karena ia meyakini bahwa tindakan yang disarankan orang lain tersebut merupakan salah satu bentuk pembuktian kepercayaan yang diberikan kepadanya. Rasa percaya tidak muncul tiba-tiba. Keyakinan pada diri seseorang atau sekelompok orang muncul dari kondisi terus menerus yang berlangsung secara alamiah ataupun dikondisikan (buatan). Rasa percaya bisa diwariskan tetapi harus dipelihara dan dikembangkan karena rasa percaya bukan merupakan hal yang absolut

Berkaitan dengan uraian tersebut di atas, maka tingkat kepercayaan pengrajin tenun di Kabupaten Muna dapat dikategorikan sebagai kriteria masyarakat yang memiliki modal sosial tinggi, karena hasil wawancara dengan informan semuanya mengatakan sangat percaya dengan LSM, koperasi, pengusaha, maupun pemerintah yang selama ini sangat memperhatikan kehidupan para pengrajin tenun tanpa memandang latar belakang dari mana mereka berasal.

\section{Aspek Nilai dan Norma}

Norma-norma terdiri dari pemahaman-pemahaman, nilai-nilai, harapanharapan dan tujuan-tujuan yang diyakini dan dijalankan bersama oleh sekelompok orang. Norma-norma dapat bersumber dari agama, panduan moral, maupun standarstandar sekuler seperti halnya kode etik profesional. Norma-norma dibangun dan berkembang berdasarkan sejarah kerjasama di masa lalu dan diterapkan untuk mendukung iklim kerjasama (Putnam, 1993; Fukuyama, 1995). Norma-norma dapat merupaka pra-kondisi maupun produk dari kepercayaan sosial

Aspek nilai atau norma dalam kerajinan tenun juga menjadi perhatian penenun. Menurut informan WN, untuk memulai mengerjakan tenun haruslah mencari hari dan waktu yang baik (orang Muna menyebutnya kutika) tidak boleh dilakukan disembarang waktu, karena ada kepercayaan di kalangan orang Muna bahwa apabila dilakukan disembarang waktu akan menyebabkan kegagalan atau hasilnya tidak maksimal. Selain itu, juga tidak dibolehkan menenun jika di tetangga dalam keadaan berduka karena bunyi menenun dapat mengganggu tetangga yang sedang berduka. Semua ini berkaitan dengan nilai dan norma yang masih berlaku dalam masyarakat

Norma yang selalu menjadi perhatian informan yang satu ini, norma yang berlaku dalam masyarakat terutama berkaitan dengan etika bisnis. Menurut informan WI sudah menjadi kebiasaan umum di kalangan penenun untuk menghargai hasil karya tenun orang lain atau tetangga, tidak boleh saling menjelek-jelekan. Selain itu menurut informan dalam menenun ada nilai estetika, ada pesan-pesan moral yang 
harus dipatuhi oleh penenun khususnya anak-anak remaja. Ketika peneliti tanyakan nilai moral apa dalam menenun, katanya sudah seharusnya bila seorang gadis pulang sekolah menggiatkan dirinya untuk menenun sebagai bekal ketika berumah tangga kelak, menjadi orang lebih tenang jika menghadapi masalah.

Informan $\mathrm{WMb}$ Norma-norma yang tertanam dalam kehidupan masyarakat pada umumnya, dan kehidupan para penenun pada khususnya sangat dijunjung tinggi. Ethos kerja yang tinggi menjadi ciri khas orang Muna, semangat gotong royong tetap terpelihara dengan baik. Selain itu, menurut informan bahwa norma yang mewajibkan bahwa seorang gadis haruslah pintar menenun, rupanya tidak lagi seketat pada masa lalu, meskipun tidak ditinggalkan sepenuhnya.

Tinggi rendahnya nilai dan norma, Sidu (2006) membaginya kedalam tiga kriteria, yaitu; (1) kriteria masyarakat yang memiliki modal sosial minimum/rendah antara lain sering tidak mentaati ajaran agama yang dianut. Hanya taat terhadap nilai dan norma yang menguntungkan diri sendiri. Hanya taat terhadap tokoh masyarakat yang ada hubungan keluarga. Kurang taat terhadap orang luar/LSM, kurang taat terhadap peraturan pemerintah, (2) kriteria masyarakat yang memiliki modal sosial dasar/sedang hanya mentaati ajaran yang diwajibkan saja. Taat terhadap nilai dan norma yang disepakati oleh komunitasnya dan tidak merugikan diri sendiri. Taat terhadap tokoh masyarakat yang memperjuangkan kepentingan keluarga dan kelompoknya. Taat kepada orang luar/LSM yang sudah dikenal dan memperjuangkan kepentingan keluarga dan kelompoknya. Taat terhadap peraturan pemerintah yang ada hubungannya dengan kepentingan diri sendiri dan kelompoknya, (3) kriteria masyarakat yang memiliki modal sosial maksimum/tinggi antara lain mentaati semua ajaran agama baik yang diwajibkan maupun yang disunahkan. Taat terhadap nilai dan norma yang berlaku secara umum dan mengakomodir kepentingan orang banyak. Taat terhadap orang luar/LSM yang bertujuan untuk membantu masyarakat banyak. Taat terhadap peraturan yang mengakomodir kepentingan masyarakat umum tanpa memandang keluarga, kelompok, suku, ras, dan agama.

Dalam kehidupan bermasyarakat para pengrajin tenun tentu saja tidak dapat melepaskan dirinya dari sistem nilai dan norma yang berlaku dalam masyarakat Muna pada umumnya maupun nilai dan norma yang berlaku di kalangan para pengrajin tenun di Kabupaten Muna.

\section{Aspek Jaringan}

Infrastruktur dinamis dari modal sosial berwujud jaringan-jaringan kerjasama antar manusia (Putnam, 1993). Jaringan tersebut memfasilitasi terjadinya komunikasi dan interaksi, memungkinkan tumbuhnya kepercayaan dan memperkuat kerjasama. Masyarakat yang sehat cenderung memiliki jaringan-jaringan sosial yang kokoh. Orang mengetahui dan bertemu dengan orang lain. Mereka kemudian membangun inter-relasi yang kental, baik bersifat formal maupun informal Putnam (1995) berargumen bahwa jaringan-jaringan sosial yang erat akan memperkuat perasaan kerjasama para anggotanya serta manfaat-manfaat dari partisipasinya itu.

Aspek jaringan menurut penjelasan informan WN bahwa jaringan akan tercipta dengan sendirinya jika seorang penenun memperhatikan kualitas, ketepatan 
dan harga bersaing. Berdasarkan pengalamannya selama ini, para pelanggannya akan berdatangan sendiri membeli kain tenun di rumahnya, baik dalam bentuk kain tenun yang sudah jadi, atau dipesan sendiri sesuai dengan motif yang diinginkan. Namun demikian, informan juga mencari jaringan-jaringan baru terutama menguhubungi agen-agen penjualan kain khas Muna yang ada di Raha (ibu kota Kabupaten Muna) maupun di Kendari (ibu kota Provinsi Sulawesi Tenggara).

Sama seperti informan sebelumnya, jaringan tidak menjadi masalah baginya, menurut informan, berdasarkan pengalaman selama 50 tahun menjadi penenun, jaringan terbentuk dengan sendirinya. Informasi menyebar dari satu konsumen ke konsumen lainnya, sehingga banyak pembeli yang datang langsung di rumahnya. Dalam hal promosi hasil-hasil tenunan, informan tidak pernah dilibatkan dalam promosi hasil-hasil tenunan baik promosi yang dilakukan pemerintah lewat pameran pembangunan maupun oleh pihak swasta. Dengan demikian, jaringan yang terbangun selama ini adalah jaringan yang terbentuk secara alamiah, tidak direncanakan, mungkin hasilnya akan berbeda jika jaringan dibentuk dengan perencanaan yang matang.

Jaringan menurut informan WT telah terbentuk sejak lama, karena jaringan penjualan sangat penting bagi kelangsungan produksi. Jaringan pemasaran selalu ia lakukan pada setiap kesempatan anta lain ketika berkunjung ke Raha (ibu kota kabupaten atau ke Kendari (ibukota provinsi) selalu membawa kain tenun untuk dipasarkan pada gerai-gerai penjual souvenir. Selain itu, untuk memperkenalkan produk-produk tenunan sering ikut promosi lewat pameran pembangunan baik pada tingkat kabupaten maupun pada tingkat propinsi lewat sanggar tenun "sepakat". Selain itu, pemasaran hasil produksi tenun biasanya pembeli datang kerumah penenun atau dengan dijual sendiri di rumah, dan melalui pedagang perantara atau koperasi.

Fungsi dan peran modal sosial menekankan pentingnya transformasi dari hubungan sosial sesaat dan rapuh seperti pertetanggaan, pertemanan, kekeluargaan menjadi hubungan yang bersifat jangka panjang yang diwarnai oleh kewajiban terhadap orang lain. Bourdieu (2012) menegaskan modal sosial sebagai sesuatu yang berhubungan satu dengan yang lain, baik ekonomi, budaya, maupun bentuk-bentuk modal sosial berupa institusi lokal maupun kekayaan sumberdaya alamnya.

Dari ketiga aspek modal sosial sebagaimana dikemukakan di atas, bagaimana fungsi dan peran modal sosial pada aspek relasi binis terhadap perkembangan kerajinan tenun Muna sebagaimana telah disajikan pada hasil penelitian sebelumnya, tampak jelas pengaruh modal sosial terhadap pengembangan dan pelestarian kerajinan tenun Muna.

\section{KESIMPULAN}

Tujuan penelitian ini adalah menyelidiki bagaimana fungsi modal manusia dan pemanfaatan modal sosial, dalam reproduksi kulttural, mengembangkan dan melestarikan kerajinan tenun Muna. Adapan kesimpulan dalam penelitian ini adalah sebagai berikut: 
Fungsi modal manusia dalam reproduksi budaya kerajinan tenun pada masyarakat Muna ditinjau dari berbagai aspek menunjukkan bahwa dari aspek pengetahuan, hampir semua informan bahwa pengetahuan yang mereka miliki sebagai penenun diperoleh melalui pewarisan pengetahuan dari orang tua mereka, dan hanya sebahagian kecil (satu) orang yang belajar dari tetangganya, namun demikian semua penenun belajar menenun secara informal. Dari aspek pengalaman sebagai penenun, rata-rata informan telah bekerja selama 20-60 tahun sehingga mereka mampu menguasai semua jenis motif dasar kain tenun Muna. Aspek kemampuan dalam menenun rata-rata informan sudah tidak diragukan lagi karena hampir semua pengrajin telah mengikuti pelatihan terutama berkitan dengan penganekaragaman motif dan penggunaan pewarna alami. Namun demikian, yang menjadi kendala bagi penenun adalah masalah pengelolaan usaha kerajinan tenun, meskipun mereka telah dilatih untuk menjadi pengusaha tenun, tetapi masih sebahagian kecil yang mampu mengelola usahanya dengan baik. Dari segi keterampilan, para pengrajin telah memiliki keterampilan yang cukup untuk menjadi seorang pengrajin yang baik, meskipun demikian keterampilan ini harus terus ditingkatkan guna menghadapi tantangan zaman yang semakin kompetitif. Aspek kreativitas dikalangan pengrajin tenun tampaknya juga menjadi perhatian mereka, hal ini terlihat dari lahirnya kreasikreasi baru dalam tenunan yang mereka produksi.

Fungsi modal sosial dalam pengembangan jaringan bisnis reproduksi budaya kerajinan tenun pada masyarakat Muna dilihat dari tiga aspek, yaitu aspek kepercayaan menunjukan bahwa tingkat kepercayaan antara penenun dan pemilik usaha, antara penenun dengan penenun, antara penenun dengan konsumen, dan antara penenun dengan pemerintah, LSM, koperasi telah terjalin suatu kepercayaan yang tinggi. Hal ini tidak mengherankan apabila antara berbagai pihak terjadi sinergitas yang saling mendukung sehingga tercipta iklim usaha yang kondusif. Dari aspek norma menunjukkan bahwa para pengrajin tenun Muna selalu memperhatikan normanorma sosial, adat istiadat yang berlaku dalam masyarakat, baik antara penenun dengan pengusaha, antar penenun, maupun dengan konsumen. Dari aspek jaringan, para pengrajin memandang sebagai sesuatu yang penting, oleh karena itu para pengrajin terus berupaya mempertahankan jaringan yang sudah ada, dan membentuk jaringan-jaringan baru, sehingga saat ini telah terbentuk jaringan penjualan dari tingkat kabupaten, yakni di Raha dan Kota Bau-Bau, tingkat propinsi di Kendari, dan tingkat nasional di Jakarta.

\section{DAFTAR PUSTAKA}

Agustang, A. (1999). Interaksi Sosial dan Perubahan Struktur Komunitas (Studi Pada Masyarakat Kawasan Industri Makassar Sulawesi Selatan).

Agustang, A. (2010). SUFISME DAN KEMISKINAN KULTURAL PADA KOMUNITAS NELAYAN DI PESISIR TELUK BONE KECAMATAN SIBULUE. $A L-F I K R, 14,342-364$. http://journal.uinalauddin.ac.id/index.php/alfikr/article/view/2327 
Andi Agustang. (2015). Dasar-Dasar Filsafat Penelitian Untuk Pengembangan Ilmu (I. I. Idrus (ed.); pertama). CV Multi Global.

Anwas, Oos M., 2013, Pemberdayaan Masyarakat di Era Global, Bandung, Penerbit Alfabeta.

Arsyad, Lincolin, dkk. 2011. Strategi Pembangunan Perdesaan Berbasis Lokal. Yogyakarta: STIM/YKPN Yogyakarta

Bourdieu P. 2013. Arena Produksi Kultural, Sebuah Kajian Sosial Budaya, Bantul, Yogyakarta, Kreasi Wacana

Chourmain, M.A.S., Imam, 2008, Acuan Normatif Penelitian Untuk Penulisan Skripsi, Tesis \& Disertasi, Jakarta, Al-Haramain Publishing House.

Damsar, dan Indrayani, 2013, Pengantar Sosiologi Ekonomi, Jakarta, Kencana Premedia Group.

Fukuyama, Francis (1995), Trust: The Social Virtues and The Creation of Prosperity, New York: the Free Press Onyx, J (1996), "The Measure of Social Capital", paper presented to Australian and New Zealand Third Sector Research Conference on Social Cohesion, Justice and Citizenship: The Role of Voluntary Sector, Victoria University, Wellington.

Fukuyama, F. 1992. The End of History and The Last Man. New York: Free Press Fukuyama F, 1999. "Social Capital and the Global Economy". Foreign Affairs, Vol 74 No 5, pp.89-97.

Hasbullah, J., 2006. Sosial Kapital: Menuju Keunggulan Budaya Manusia Indonesia. Jakarta: MR-United Press.

Putnam R, 1995. Bowling Alone: America's eclining Social Capital. Journal of Democracy.

Putnam. 1993, Making Democracy Work: Civic Traditions in Moder Coleman JS, 1988. "Social Capital in the Creation of Human Capital". American Journal of Sociology. Vol 94 No 5, pp 95-121.

Ritzer, George dan Goodman, Douglas J. 2007. Teori Sosiologi Modern. Jakarta: Prenada Media.

Ratna, I Nyoman Kutha, 2004, Teori, Metode, dan Teknik Penelitian Sastra dari Strukturalisme Hingga Poststrukturalisme Perspektif Wacana Naratif, Yogyakarta, Pustaka Pelajar. 
Syahyuti. 2008. Peran Modal Sosial (Sosial Capital) Dalam perdagangan Hasil Pertanian. (The Role Sosial Capital In Agricultural Trade), Jurnal Forum Penelitian Agro Ekonomi. Vol 26(1): 32-43.

Sidu, Dasmin, 2006, Pemberdayaan Masyarakat Sekitar Kawasan Hutan Lindung Jompi, Kabupaten Muna Provinsi Sulawesi Tenggara, Disertasi, Sekolah Pascasarjana Institut Pertanian Bogor, Tidak dipublikasikan

Spellerberg, Anne. 1997. "Towards a Framework for the Measurement of Social Capital" dalam David Robinson (ed), Social Capital dan Policy Development, Wellington: The Institute of Policy Studies, halaman 42-52.

Stockey, Derek, 2003, Human Capital Concept-Definition and Explanation, Google Website on the Human Capital Management Definition.

Suharto, Edi (2005a), Analisis Kebijakan Publik: Panduan Praktis Mengkaji Masalah dan Kebijakan Sosial, Bandung: Alfabeta.

Suharto, Edi (2005b), Membangun Masyarakat Memberdayakan Rakyat: Kajian Strategis Pembangunan Kesejahteraan Sosial dan Pekerjaan Sosial, Bandung: Refika Aditama.

Thhee, Kian Wie, 2006, Policies for Prifat Sector Development in Indonesia; SME, Promotion Policies for Indonesia, ADBI, Asian Development Bank, Paper No. 26, Published March 2006.

Tonkiss, F., 2000, Trust Social Capital and Economy dalam F. Tonkiss dan A. Pasey (eds) Trust and Civil Society, New York, St. Martin's.

\section{Sumber Inspirasi}

Ma'na, P., Agustang, A., Salusu, J., Ikhsan, A., \& Dirawan, G. D. (2015). Decision making strategic value based local wisdom Tongkonan North Toraja. Man India, 95(3), 633-639.

Upe, A., Salman, D., \& Agustang, A. (2019). The effects of the exploitation of natural resources towards risk society construction in Southeast Sulawesi Province, Indonesia. Journal of Degraded and Mining Lands Management, 6(2), 1587.

Awaru, A. O. T., Idris, R., \& Agustang, A. (2018, October). Sexual Education at High School Sinjai East. In 1st International Conference on Social Sciences (ICSS 2018). Atlantis Press. 
Idris, M., Ramli, M., Agustang, A., \& Kesuma, A. I. (2015). Bureaucracy Ethics Based in Public Service Local Wisdom in Gowa. Mediterranean Journal of Social Sciences, 6(6 S4), 419-419.

Agustang, A., Pada, A. T., \& Bastiana, M. (2018, October). Social Interaction of Local Communities With Migrants and Changes in The Structure of Local Communities (Study on Plural Society in Makassar Industrial Area). In 1st International Conference on Social Sciences (ICSS 2018). Atlantis Press.

Wardah, S., Salman, D., Agustang, A., \& Fahmid, I. M. (2017). The Contestation of Organic and Non-Organic Agricultural Knowledge in Sustainable Agriculture. Mediterranean Journal of Social Sciences, 8(2), 245-245.

Agustang, A. (2018). SIMBOLIKHAJI: Studi Deskriptif Analitik pada Orang Bugis. Al-Qalam, 15(2), 317-334.

Pannyiwi, R., Agustang, A., Kasnawi, T., Pada, A. T., Yani, A., \& Syam, S. (2020). Social Network for Drug Circulation in Sidenreng Rappang Regency, Indonesia. Systematic Reviews in Pharmacy, 11(9), 575-577.

Agustang, A., \& Soelthan, A. (2015). Analysis of the Inhibiting Factors of Transparency in the Implementation of Local Governance. Mediterranean Journal of Social Sciences, 6(6 S4), 464.

Nain, U., \& Agustang, A. (2020). Analysis On The Utilization Of Village Funds In Cash For Work Program In Bulukumba Regency, South Sulawesi Indonesia. International Journal of Advanced Science and Technology, 29(7s), 2811-2818.

Azis, F., Idris, R., \& Agustang, A. (2017). Involution Fisheries: Post-Study Model of National Program in Integrated Movement at Community Fishermen's Village Development Arungkeke, Jeneponto. Mediterranean Journal of Social Sciences, 8(1), 441.

Agustang, A. D. M. P., \& Nur, H. (2020). Konflik Mahasiswa Parang Tambung Universitas Negeri Makassar. Phinisi Integration Review, 3(1), 46-54.

Rasyid, R., Agustang, A., Maru, R., Agustang, A. T. P., \& Sudjud, S. (2020). PENYULUHAN PENCEGAHAN PENYALAHGUNAAN NARKOBA DI KALANGAN PELAJAR SMP NEGERI 6 DUAMPANUA KABUPATEN PINRANG. JMM (Jurnal Masyarakat Mandiri), 4(2), 116-123.

Rahmania, S., \& Agustang, A. (2017). PRESEPSI MAHASISWA FIK TERHADAP PENYIMPANGAN SEKSUAL LESBIAN (STUDI KASUS PADA MAHASISWA FIK UNM). JURNAL SOSIALISASI, 162-168.

Ashar, A., \& Agustang, A. (2020). Dampak Sosial Dana Desa Dalam Kesejahteraan Masyarakat Di Desa Kalola, Kecamatan Maniangpajo, Kabupaten 
Wajo. Jurnal Sosialisasi: Jurnal Hasil Pemikiran, Penelitian dan Pengembangan Keilmuan Sosiologi Pendidikan, (1), 19-25.

Yusuf, M., \& Agustang, A. (2020). DINAMIKA PERUBAHAN SOSIAL EKONOMI PADA MASYARAKAT KINDANG KABUPATEN BULUKUMBA. Jurnal Sosialisasi: Jurnal Hasil Pemikiran, Penelitian dan Pengembangan Keilmuan Sosiologi Pendidikan, (2), 31-37.

Fransina, M., \& Andi, A. (2019). THE ANALYSIS OF EXISTENCE OF MIGRATION IN THE CONTEXT OF BASUDARA COMMUNITY IN AMBON CITY, INDONESIA. Russian Journal of Agricultural and SocioEconomic Sciences, 94(10).

Usman, A., Agustang, A., Djalal, D., \& Annas, S. (2018, October). The Contribution Of Supporter Community In Maximizing Their Role For The Advancement Of Makassar Football Club (PSM). In 1st International Conference on Social Sciences (ICSS 2018). Atlantis Press.

Agustang, A., \& Oruh, S. Factors affecting of heropnam of mental disorders in Dadi Regional Hospital in South Sulawesi Province. Man In India, 97(11), 233244.

Pratiwi, E. L., \& Agustang, A. (2018). PERSEPSI ORANGTUA SISWA TERHADAP TINDAKAN GURU DALAM MENDISIPLINKAN SISWA DI SMK YPKK LIMBUNG. JURNAL SOSIALISASI, 6-10.

Asri, A., Kasnawi, T., \& Agustang, A. Actors' Social Tensions on Traditional Birth Attendants and Midwife Partnerships in Childbirth Assistance (Sociology of Health Study in Bulukumba Regency).

Bahri, S., Kasnawi, T., Agustang, A., \& Adam, A. (2017). Vegetarian Community Social Movement (Analysis of Health Sociology in Makassar). The Social Sciences, 12(10), 1824-1831.

Djalante, A., Agustang, A., Tahmir, S., \& Sahabuddin, J. A Disadvantaged Tribe in Bajoe Village, Bone Regency: A Phenomenological Research on Bajo Tribe's Social Life in Bone Regency, South Sulawesi.

Rahmawati, R., \& Agustang, A. (2018). PERBANDINGAN POLA ASUH ORANG TUA SISWA BERPRESTASI DENGAN SISWA YANG TIDAK BERPRESTASI DI SMA NEGERI 2 GOWA. JURNAL SOSIALISASI, 115-119.

Agustang, A. (2018). PERAN WALI KELAS DALAM PENYELESAIAN KONFLIK ANTAR SISWA DI SMA NEGERI 1 PINRANG. JURNAL SOSIALISASI, 12-16. 
Irnawaty, I., \& Agustang, A. (2019). SMARTPHONE ADDICTION PADA MAHASISWA PENDIDIKAN SOSIOLOGI FAKULTAS ILMU SOSIAL UNIVERSITAS NEGERI MAKASSAR. JURNAL SOSIALISASI, 41-46.

Zainuddin, M., \& Agustang, A. (2019). KONTROL SOSIAL ORANGTUA TERHADAP PENGGUNAAN SMARTPHONE PADA REMAJA (STUDI DI DESA GIRING-GIRING KECAMATAN BONTONMPO KABUPATEN GOWA. JURNAL SOSIALISASI, 68-73.

Sofyan, Y., \& Agustang, A. (2018). PENERAPAN MODEL PEMBELAJARAN KOOPERATIF TIPE NHT (NUMBERED HEADS TOGETHER) TERHADAP KEAKTIFAN BELAJAR SISWA KELAS XI IPS 1 SMAN 8 MAKASSAR. JURNAL SOSIALISASI, 158-165.

Agustang, A. (2018). PENERAPAN PUNISHMENT DALAM MEMBENTUK $\begin{array}{llllll}\text { KARAKTER DISIPLIN SISWA DI } & \text { SMA NEGERI } & 1\end{array}$ TAKALAR. JURNAL SOSIALISASI, 126-130.

Amiruddin, T. K., Agustang, A., \& Idris, R. (2014). RELIGIOUS CONVERSION IN MARRIED LIFE IN MAKASSAR, THE CASE OF CHRISTIANITY TO ISLAM. JOURNAL OF ACADEMIC RESEARCH, 6(6), 264.

Machmuddin, H., Agustang, A., Kahar, F., \& Bustan, N. (2015). IMPROVING THE QUALITY OF PRIMARY HEALTH SERVICES IN THE PERSPECTIVE OF PARTICIPATORY GOVERNANCE. International Journal of Academic Research, 7(1).

Agustang, A., \& Sahabuddin, J. (2020, October). MODEL KOLABORASI SOSIAL PENDIDIKAN KARAKTER DI SEKOLAH SWASTA KECAMATAN BISSAPPU KABUPATEN BANTAENG. In PROSIDING SEMINAR DAN DISKUSI PENDIDIKAN DASAR.

Astinah, A., Idris, R., \& Agustang, A. (2020). AGILE LEADERSHIP AND DIVORCE EDUCATION: STUDY ON WOMEN'S PERCEPTION. Humanities, 8(3), 323-330.

Muis, I., Agustang, A., \& Adam, A. (2020). Elderly Poverty: Social Demographic, Work Distribution, Problem Health \& Social Protection. Asian Journal of Social Sciences \& Humanities Vol, 9(1).

Agustang, A. (2020). Symbolic Violence towards Students in the Context of the Existence of the Stereotypical Frames of Lecturers and Students in the Higher Education System in Indonesia. PalArch's Journal of Archaeology of Egypt/Egyptology, 17(2), 249-258.

Asrifan, A. (2009). Using songs in teaching English language for the young learners. ParePare: unpublished. 
Puasa, K., Asrifan, A., \& Chen, Y. (2017). Classroom Talk in Bilingual Class Interaction. Research in Pedagogy, 7(1), 106-121.

Nadirah, N., Tahir, M. H., \& Asrifan, A. (2019). THE ABILITY TO TRANSLATE ENGLISH PHRASES INTO INDONESIAN AND THE DIFFICULTIES FACED BY THE ELEVENTH GRADE STUDENTS OF SMAN 1 PANCARIJANG. JOURNAL OF ADVANCED ENGLISH STUDIES, 2(1), 41-46.

Apdy, A. P. R., \& Asrifan, A. (2019, April). The Chinese mime game in teaching vocabulary on EFL classroom. In PROCEEDINGS OF THE 65th TEFLIN INTERNATIONAL CONFERENCE (Vol. 65, No. 01).

Taslim, T., Asrifan, A., Chen, Y., \& Nurdania, N. R. (2019). CORRELATION BETWEEN STUDENT'S VOCABULARY MASTERY AND SPEAKING SKILL. JOURNAL OF ADVANCED ENGLISH STUDIES, 2(2), 65-76.

Muthmainnah, M., Asrifan, A., Al Yakin, A., \& Sahabuddin, C. (2019, April). The use of dictogloss technique on ELT classroom: An experiment study of students listening comprehension. In PROCEEDINGS OF THE 65th TEFLIN INTERNATIONAL CONFERENCE (Vol. 65, No. 01).

Mutmainnah, M., Azis, S., Maulidya, U., \& Asrifan, A. (2017). Glory Style in Mandar Song Lyrics: A study of Mandar Tribe in South Sulawesi, Indonesia. JOURNAL OF ADVANCES IN LINGUISTICS, 8(1), 12861291.

Asrifan, A., Rinantanti, Y., Tang, S., \& Nadirah, N. (2019). THE 3-DIMENSION PICTURES IN INCREASING THE STUDENTS ABILITY AND INTEREST TO WRITE DESCRIPTIVE COMPOSITION. JOURNAL OF ADVANCED ENGLISH STUDIES, 2(1), 19-30.

Asrifan, A., Nadira, N., \& Haedar, H. (2018). IMPROVING STUDENTS'READING COMPREHENSION OF DESCRIPTIVE TEXT THROUGH COLLABORATIVE MURDER. JOURNAL OF ADVANCED ENGLISH STUDIES, 1(2), 21-31.

Asrifan, A. (2015). Analysis of English Students' Learning Style in Bilingual Class. International Journal of Literature and Arts, 3(4), 34.

Farahdiba, S., \& Asrifan, A. (2016). Speaking Ability and Psychological Barriers of the Second Year Students of Hotel Department of SMKN 1 Sidenreng Kabupaten Sidrap in Speaking English. Asian EFL Journal, (89), 41.

Asrifan, A. (2012). Increasing the Students Ability to Write Descriptive Composition at SMP Negeri 13 Parepare by using the 3-Dimension Pictures. 
Tang, S., Asrifan, A., Chen, Y., Haedar, H., \& Agussalim, M. (2019). THE HUMOR STORY IN TEACHING READING COMPREHENSION. JOURNAL OF ADVANCED ENGLISH STUDIES, 2(2), 77-87.

Nurwanti, N., Asrifan, A., \& Haedar, H. (2019). THE APPLICATION OF COOPERATIVE LEARNING: JIGSAW II TECHNIQUE IN IMPROVING STUDENTS'READING COMPREHENSION OF EXPOSITORY TEXT. JOURNAL OF ADVANCED ENGLISH STUDIES, 2(1), 31-40.

Asrifan, A. (2016). The Effectiveness of Think-Pair-Share Technique in Improving Studentsâ $€^{\mathrm{TM}}$ Speaking Ability and Interest. English Literature and Language Review, 2(3), 24-35.

Asrifan, A., Muthmainnah, M., Al-Yakin, A., Sahabuddin, C., \& Haedar, H. (2018). THE CAUSE-EFFECT TECHNIQUE IN TEACHING RECOUNT WRITING. JOURNAL OF ADVANCED ENGLISH STUDIES, 1(2), 63-72.

Asrifan, A., Vargheese, K. J., Syamsu, T., \& Amir, M. (2020). ESP COURSE DESIGN: THE NEED ANALYSIS ON TOURISM DEPARTMENT IN INDONESIA VOCATIONAL HIGH SCHOOLS. JOURNAL OF ADVANCED ENGLISH STUDIES, 3(2), 69-77.

Asrifan, A., Ghofur, A., \& Azizah, N. (2020). Cheating Behavior in EFL Classroom (A Case Study at Elementary School in Sidenreng Rappang Regency). OKARA: Jurnal Bahasa dan Sastra, 14(2), 279-297.

Nadirah, N., Asrifan, A., Vargheese, K. J., \& Haedar, H. (2020). INTERACTIVE MULTIMEDIA IN EFL CLASSROOM: A STUDY OF TEACHING READING COMPREHENSION AT JUNIOR HIGH SCHOOL IN INDONESIA. JOURNAL OF ADVANCED ENGLISH STUDIES, 3(2), 131-145.

Muthmainnah, A. R., Atmowardoyo, H., Salija, K., \& Asrifan, A. (2020). Literary Work as Teaching Materials: A Study of Students and Lecturers Needs Analysis. Solid State Technology, 63(5), 394-407.

Tilome, A. A., Agustang, A., Jasruddin, M. S., \& Asrifan, A. (2020). Social Exchange of Political Elites in the Regional Leader Election of Gorontalo Province, Indonesia. Solid State Technology, 63(5), 521-531.

Pacinongi, A., \& Asrifan, A. (2020). Bimbingan Pengawas Berkelanjutan dalam Mewujudkan Pendidikan Karakter Bangsa dalam Kegiatan Belajar Mengajar Penjaskes. Celebes Education Review, 2(1), 1-7.

Gunawan, G., \& Asrifan, A. (2020). Penerapan Kerja Kelompok Kegiatan MGMP Guru Ekonomi dalam Menyusun RPP untuk Meningkatkan Kompetensi Pedagogik. Celebes Education Review, 2(1), 31-36. 
Yusuf, I., \& Asrifan, A. PENINGKATAN AKTIVITAS KOLABORASI PEMBELAJARAN FISIKA MELALUI PENDEKATAN STEM DENGAN $\begin{array}{lllllll}\text { PURWARUPA } & \text { PADA } & \text { SISWA } & \text { KELAS XI IPA } & \text { SMAN } 5\end{array}$ YOGYAKARTA. Editorial Team, 32.

Al Yakin, A., Sahabuddin, C., Rahayu, A., Fitrah, N., \& Arifin, M. (2020). Political Celebrification and Electability: A Study of Political Phenomena Imaging in Election Polewali Mandar District, West Sulawesi, Indonesia. Solid State Technology, 63(5), 632-646.

Junaedah, S. B. T., \& Ahmad, M. A. (2020). The Outdoor Learning Modules Based on Traditional Games in Improving Prosocial Behaviour of Early Childhood. International Education Studies, 13(10).

Octaberlina, L. R., \& Muslimin, A. I. (2020). Efl students perspective towards online learning barriers and alternatives using moodle/google classroom during covid-19 pandemic. International Journal of Higher Education, 9(6), 1-9.

Octaberlina, L. R., \& Anggarini, I. F. (2020). Teaching vocabulary through picture cards in Islamic Elementary School: a case study in Nida Suksa School, Thailand. Jurnal Madrasah, 13(1), 26-38.

Octaberlina, L. R. (2016). Plagiarism in English language theses in Indonesia. Jurnal Ilmu Pendidikan, 14(3).

Octaberlina, L. R., \& Anggarini, I. F. (2020). Teaching vocabulary through picture cards in Islamic Elementary School: a case study in Nida Suksa School, Thailand. Jurnal Madrasah, 13(1), 26-38.

Asrifan, A., Zita, C. T., Vargheese, K. J., Syamsu, T., \& Amir, M. (2020). THE EFFECTS OF CALL (COMPUTER ASSISTED LANGUAGE LEARNING) TOWARD THE STUDENTS'ENGLISH ACHIEVEMENT AND ATTITUDE. JOURNAL OF ADVANCED ENGLISH STUDIES, 3(2), 94-106.

Asrifan, A. (2021). ACADEMIC WRITING. LawArXiv. January, 2. https://doi.org/10.31228/osf.io/x2s7e

Asrifan, A. (2020). TUTORIAL PENGGUNAAN QUIZIZZ (www. quizizz. com) PADA PEMBELAJARAN. https://doi.org/10.31219/osf.io/kqnza

Asrifan, A. (2021). Abd Ghofur.“. THE USE OF READING CIRCLES IN INCREASING STUDENTS SPEAKING ABILITY AT THE ELEVENTH GRADE SMK NEGERI, 1. https://doi.org/10.31219/osf.io/8vjxy

Asrifan, A. (2020). Pandemic, Humanity and Education. https://doi.org/10.31219/osf.io/q2gpk 
Asrifan, A. (2021). USING CAT AND MOUSE GAME TO IMPROVE STUDENT'S SPEAKING ABILITY AT THE ELEVENTH GRADE OF MA YMPI RAPPANG. https://doi.org/10.31219/osf.io/phtvn

Asrifan, A., \& Ghofur, A. (2021). THE USE OF READING CIRCLES IN INCREASING STUDENTS SPEAKING ABILITY AT THE ELEVENTH GRADE SMK NEGERI 1 PANCARIJANG. https://doi.org/10.31219/osf.io/8vjxy

Asrifan, A. (2021). Book Review: Halliday. 1989. Spoken and Written Language. Oxford University Press. https://doi.org/10.31219/osf.io/ej8tb

Asrifan, A., \& Ghofur, A. (2021). TALK, ACTION, SILENCE, INTERRUPTION AND THEIR IMPLICATIONS IN BUGINESE SOCIETY (SOPPENG REGENCY). https://doi.org/10.31219/osf.io/pv3ku

Asrifan, A. (2020). PENILAIAN BERBASIS ANDROID MENGGUNAKAN APLIKASI PLICKERS. https://doi.org/10.31219/osf.io/htreq

Sapulette, A. A., Agustang, A., \& Syukur, M. Actor Construction in the Frame of Diversity to Achieve Social Harmony in the Life of Tamilouw Village Society Seram Island-Maluku.

Amiruddin, T. K., Agustang, A., \& Idris, R. (2014). RELIGIOUS CONVERSION IN MARRIED LIFE IN MAKASSAR, THE CASE OF CHRISTIANITY TO ISLAM. JOURNAL OF ACADEMIC RESEARCH, 6(6), 264.

Machmuddin, H., Agustang, A., Kahar, F., \& Bustan, N. (2015). IMPROVING THE QUALITY OF PRIMARY HEALTH SERVICES IN THE PERSPECTIVE OF PARTICIPATORY GOVERNANCE. International Journal of Academic Research, 7(1).

Agustang, A., \& Sahabuddin, J. (2020, October). MODEL KOLABORASI SOSIAL PENDIDIKAN KARAKTER DI SEKOLAH SWASTA KECAMATAN BISSAPPU KABUPATEN BANTAENG. In PROSIDING SEMINAR DAN DISKUSI PENDIDIKAN DASAR.

Mutiara, I. A., Agustang, A., Adam, A., Upe, A., \& Equatora, M. A. (2020). The dynamics of prostitutes lives in metropolitan cities. Journal of Critical Reviews. https://doi. org/10.31838/jcr, 7, 165.

Haulussy, R. H., Najamuddin, I. R., \& Agustang, A. D. M. P. (2020). The sustainability of the Sasi Lola tradition and customary law (Case study in Masawoy Maluku, Indonesia). Intl J Sci Technol Res, 9(2), 5193-5195.

Agustang, A. (2020). Symbolic Violence towards Students in the Context of the Existence of the Stereotypical Frames of Lecturers and Students in the Higher Education System in Indonesia. PalArch's Journal of Archaeology of Egypt/Egyptology, 17(2), 249-258. 
Agustang, A. (2015). Dasar-Dasar Filsafat Penelitian Untuk Pengembangan Ilmu.

Agustang, A. T. P. Muh. Said, dan Rusman Rasyid. 2015. Perkembangan Peran Jender Dalam Prespektif Teori Androgini, 1-8.

Rasyid, R., Agustang, A., Agustang, A. T. P., Bastiana, B., \& Najamuddin, N. Analisis Faktor Yang Mempengaruhi Status Kemiskinan Rumah Tangga Pada Wilayah Central Bussiness District (CBD) di Kota Makassar. Majalah Geografi Indonesia, 34(1), 43-52.

Asmi, A. S., Kasnawi, M. T., Agustang, A., \& Yani, A. (2020). Sociocultural Transformation in Efforts to Reduce Mortality of Infants in Bone Regency, Indonesia. Systematic Reviews in Pharmacy, 11(10), 762-765.

Agustang, A. (2020, October). Social Actions of Galla Actors in the Kaemba Maros Traditional Village Community Sulawesi Selatan. In 3rd International Conference on Social Sciences (ICSS 2020) (pp. 748-753). Atlantis Press.

Agustang, A. (2020). The Symbolic Violence Towards Private School Students Through The Frame Stereotype In Bantaeng District Of Indonesia. Prosiding ICoISSE, 1(1), 578-588.

Ariani, A. I., Agustang, A., Adam, A., \& Alimsyah, S. (2020). INSTITUTIONAL FAILURES IN THE WORLD OF EDUCATION IN SCHOOLS FOR CHILDREN VICTIMS OF PARENTS. Asian Journal of Social Sciences \& Humanities Vol, 9, 2. 
